\title{
Covid-19: Lack of PPE in care homes is risking spread of virus, leaders warn
}

\author{
Gareth lacobucci
}

The BMJ

A lack of access to personal protective equipment (PPE) and staff testing in care homes poses a major risk of covid-19 being spread, sector leaders have warned. Care homes have been identified as one of the biggest potential risks for virus spreading, owing to the number of elderly residents with underlying health conditions.

At a health select committee hearing hosted remotely on 26 March, Sarah Pickup, the deputy chief executive of the Local Government Association, said that more equipment and testing was needed to protect both residents and workers. "Access to PPE is insufficient in the care sector," she said, warning that people entering care homes on discharge from hospital could bring an infection.

"The government is doing its best to get things out to people, but it's very difficult to have enough. I have heard care homes saying, we can do barrier nursing if we've got the testing and the kit, and we know who is positive and who isn't. But we really have got to get the flows of equipment and testing as soon as is practicable." Pickup urged that when testing capacity becomes available, the care sector must be among the places where testing is prioritised.

The session also heard from Martin Green, the chief executive officer of Care England, who stressed the importance of testing staff to keep healthy people in work. "We have to recognise that we are in uncharted waters, and this is a complete emergency. If we have our staff going off and following the advice to self-isolate, we will have a major problem in our care homes. We need to have testing so that we can bring people back into the workforce," he said.

James Bullion, vice president of the Association of Directors of Adult Social Services, warned that, although the additional $£ 1.6 \mathrm{bn}$ ( $€ 1.7 \mathrm{bn} ; \$ 1.9 \mathrm{bn}$ ) announced for the care sector was welcome, it might not reach very far. "It is already very clear that the costs involved in providers taking on agency staff, dealing with sickness, PPE, and so on is likely to be $30-40 \%$ higher than the usual rate we would pay, so we are going to have to pay our way out of trouble on this issue, and we might have to come back for additional funding," he warned.

"If the care sector was not so stressed by the past 6-7 years of the funding regime that we've had, then we would be in a much better state," he said. Bullion also warned that the NHS's target to deliver an additional 15000 extra acute care beds through quicker discharge was "very ambitious."

"The first limiting factor on our success will be PPE and providers feeling assured that they can take the people either into care homes or back at home with home care. The second will be the workforce; there are currently 122000 vacancies in social care. Thirdly, the flow arrangements from hospitals are still not perfect for identifying the people who are safe for discharge-even with the removal of bureaucracies."

1 Health and Social Care Committee. 26 March 2020. https://parliamentlive.tv/Event/Index/ bbe513cc-8366-43be-99e5-7a0b721fcdfd

Published by the BMJ Publishing Group Limited. For permission to use (where not already granted under a licence) please go to http://group.bmj.com/group/rights-licensing/ permissions 